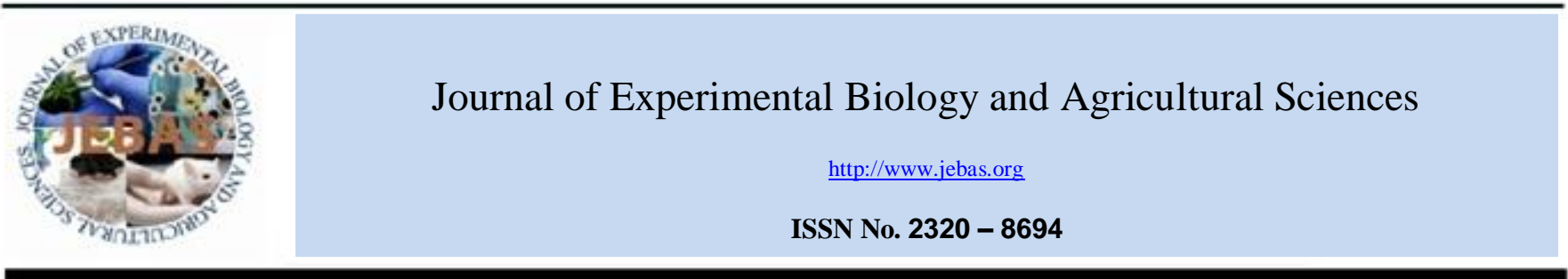

\title{
ENZYME-BASED BIODEGRADATION OF HAZARDOUS POLLUTANTS - AN OVERVIEW
}

\author{
Ishtiaq Ahmed ${ }^{1}$, Hafiz M. N. Iqbal ${ }^{2, *}$, Kuldeep Dhama ${ }^{3}$ \\ ${ }^{1}$ School of Medical Science, Gold coast campus, Griffith University, Southport QLD 4222, Australia \\ ${ }^{2}$ Tecnologico de Monterrey, School of Engineering and Sciences, Campus Monterrey, Ave. Eugenio Garza Sada 2501, Monterrey, N.L., CP 64849, Mexico; \\ ${ }^{3}$ Division of Pathology, ICAR-Indian Veterinary Research Institute, Izatnagar, Bareilly, Uttar Pradesh, India;
}

Received - March 11, 2017; Revision - August 2, 2017; Accepted - August 25, 2017

Available Online - September 10, 2017

DOI: http://dx.doi.org/10.18006/2017.5(4).402.411

\section{KEYWORDS}

Biodegradation

Enzymes

ECs

EPs

Hazardous pollutant

\begin{abstract}
There has always been a paramount concern over the widespread occurrences of various pollutant types, around the globe. With ever increasing scientific knowledge, socio-economic awareness, human health problems and ecological apprehensions, people are more concerned about the widespread environmental pollutants. Thus, the occurrences of newly identified pollutants so-called "emerging pollutants - EPs or emerging contaminants - ECs" in our main water bodies is of continued and burning concern worldwide. The undesirable EPs/ECs are being discharged knowingly/unknowingly with/without partial treatments into the aquatic environments that pose serious health issues and affect the whole living ecosystem. So far various approaches have been developed for the degradation of environmental pollutants to decrease their impact on the environment and are divided into three broad categories i.e. (1) physical, (2) chemical and (3) biological. Based on the literature evidence, many previous or ongoing studies have focused on contaminants degradation potentialities of the above mentioned three possible categories. However, the experimental evidence is lacking to enable specific predictions about EPs/ECs mechanistic degradation fate across various in-practice systems. This study overviews the biological degradation at large and enzyme-based degradation of hazardous pollutants in particular. Towards the end, the novel characteristics and unique enzyme system of White Rot Fungi (WRF) are also discussed to present their potentialities and implementation against a broader spectrum of EPs/ECs.
\end{abstract}

* Corresponding author

E-mail: hafiz.iqbal@my.westminster.ac.uk; hafiz.iqbal@itesm.mx (Hafiz M. N. Iqbal)

Peer review under responsibility of Journal of Experimental Biology and Agricultural Sciences.

Production and Hosting by Horizon Publisher India [HPI] (http://www.horizonpublisherindia.in/).

All rights reserved.
All the article published by Journal of Experimental Biology and Agricultural Sciences is licensed under a Creative Commons Attribution-NonCommercial 4.0 International License Based on a work at www.jebas.org.

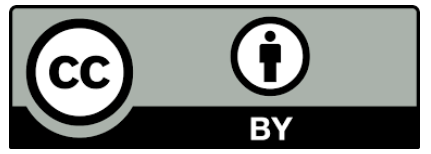




\section{Introduction}

The hazardous contaminants/pollutants which are dangerous and toxic in nature mainly originate from various industrial sectors (Asgher et al., 2016; Chatha et al., 2017). Thus, environmental pollution is rapidly expanding with increased development in the entire industrial sector. Water is contaminated by an ample variety of contaminants which is a significant threat to the whole living environment and constituting as impediment to free penetration of light in water hence affecting photosynthesis capability of aquaculture plants (Romero et al., 2006; Asgher et al., 2012a; Asgher et al., 2013; Asgher \& Iqbal 2013; Iqbal \& Asgher 2013; Bilal et al., 2017a; Bilal et al., 2017b; Bilal et al., 2017c; Bilal et al., 2017d). Owing to their health hazard nature and severe danger to the living ecosystem, research is underway around the globe to address or tackle this problematic issue with utmost care.

Herein, we reviewed the biological degradation at large and enzyme-based degradation of hazardous pollutants in particular. Towards the end, the novel characteristics and unique enzyme system of White Rot Fungi (WRF) are also discussed to present their potentialities and implementation against a broader spectrum of hazardous contaminants/pollutants including emerging pollutants/emerging contaminants (EPs/ECs).

\section{Emerging pollutants/emerging contaminants (EPs/ECs)}

According to the US Environmental Protection Agency (US EPA), the EPs/ECs are defined as: "chemicals and other substances that have no regulatory standard, have been recently "discovered" in natural streams (often because of improved analytical chemistry detection levels), and potentially cause deleterious effects in aquatic life at environmentally relevant concentrations" (Deblonde et al., 2011). There has been increasing apprehension over life-threatening pollutants so-called "emerging pollutants - EPs or emerging contaminants - ECs," which are toxic, carcinogenic, and mutagenic in nature. The reported consequences of many hazardous compounds including EPs/ECs include endocrine disruption, genotoxicity, chronic ecotoxicity, encouragement of antibiotic resistance, and uptake into the food chain, etc. (Ding \& He 2010; Arnold et al., 2013; Norvill et al., 2016). In 1996, the Food Quality Protection Act (FQPA) and amendments to the Safe Drinking Water Act (SDWA) have authorized the US Environmental Protection Agency (US EPA) to screen all chemicals in manufacturing or processing where drinking water and/or food supply line could be contaminated (Snyder et al., 2003; Filali-Meknassi et al., 2004; Bolong et al., 2009).

\subsection{Potential source of various EPs/ECs}

Various in-practice processing approaches from different sectors including industrial, pharmaceuticals, cosmeceuticals, nutraceuticals, biomedical, veterinary medicines, nanoparticles from toxic materials and perfluorinated compound among many others are considered as a potential source of various EPs/ECs (Lapworth et al., 2012; Arnold et al., 2013; Marcoux et al., 2013; Brookes et al., 2014; Norvill et al., 2016; Bilal et al., 2017d). More specifically, significant sources include municipal biosolids, landfills and associated leachates, domestics septic systems, aquaculture related systems, elevated fertilizer practices, municipal and industrial wastewater treatment sectors. EP/EC is a broader phrase that refers to a variety of pollutants/contaminants that have recently validated with the advent of highly sensitive and precise analytical techniques which are more reliable both quantitatively and qualitatively. In this regard, the USGS Toxic Substances Hydrology Program (http://toxics.usgs.gov/regional/emc/index.html) has developed and introduced analytical techniques for EPs/ECs. Moreover, the potential environmental matrices including groundwater, surface water, soil, sediment, sludge, and bio-solids have been recommended to investigate to tackle the widespread occurrences of EPs/ECs. As discussed earlier, EPs/ECs include a broader spectrum of human-made chemical compounds e.g. pesticides, cosmetics, fertilizers, household items, dyes or pigments among others, which are requisite for the society of the modern world (Thomaidis et al., 2012; Gavrilescu et al., 2015). In between the 1930 s to 2000s, an enormous increase in the chemicals production from 1 million to 400 million tons per each year has been reported in the literature (WWF, TOXIC CHEMICALS; Gavrilescu et al., 2015). According to the careful statistics by EUROSTAT published in 2013, between 2002 to 2011 approximately more than $50 \%$ of the chemical production includes environmentally harmful compounds, and among them, over 70\% were with sensational environmental concerns (EUROSTAT, 2013). Numerous reports are available that indicate the amounts of chemicals used in various textile processes from preparation to finishing varies from $10 \%$ to over $100 \%$. This extensive practice is responsible for the generation of heavy chemicals, which are toxic in nature, into the environment, especially industrial-based original dyes and dyes based toxic wastewater effluents (Bilal et al., 2016; Bilal et al., 2017a; Bilal et al., 2017b; Bilal et al., 2017c; Bilal et al., 2017d).

Some potential EPs/ECs sources includes human-made synthetic compounds, veterinary medicines e.g. antibiotic agents, hormonebased, both, natural and synthetic ones, nanoparticles from nanomaterials with toxic effects, naturally produced toxic compounds by microbes and plants, fertilizer-based compounds, both, synthetic and bio-fertilizers, physical, chemical, and 
biological reaction metabolites or by-products and medicinal agents from pharmaceuticals, cosmeceuticals and biomedical. The points mentioned above are some examples only. A comprehensive list of EPs/ECs classes along with model substances is available on the EU NORMAN network website (www.norman-network.net).

\section{Enzyme-based strategies - A potential to degrade pollutants}

In the last few years, researchers have published several research articles and scholarly reviews by highlighting this problematic issue with regard to the design and operation of enzymatic reactors and fluidized bed reactors for the degradation of recalcitrant compounds and wastewater treatments, respectively (Eibes et al., 2007; Bello et al., 2017), biodegradation of industrial pollutants by white rot fungi and their enzyme system (Asgher et al., 2008; Asif et al., 2017), emerging pollutants in the environment and their degradation aspects (Thomaidis et al., 2012; Marcoux et al., 2013; Gavrilescu et al., 2015; Norvill et al., 2016), immobilized ligninolytic enzymes as an innovative and environmental responsive technology to tackle dye-based industrial pollutants (Bilal et al., 2017a), bio-based degradation of emerging endocrine-disrupting and dye-based pollutants (Bilal et al., 2017d). Furthermore, Liu et al. (2009) and Ahmed et al. (2017) discussed major strategies including physical, chemical and biological and their potential to remove emerging contaminants e.g. endocrine disrupting compounds (EDCs) from wastewater. In another review work, Verlicchi et al. (2012) summarized contaminants removal efficacy of conventional activated sludge systems. Recently, Bilal et al. (2017a) have published a review with particular emphasis on the recent achievements of carrier-immobilized lignin-modifying enzymes (LMEs) for the degradation, decolorization, or detoxification of industrial dyes and dye-based industrial wastewater effluents. In the same study, they have discussed various immobilization strategies, physiochemical characteristics of immobilized LMEs and their environmental applications. This study overviews the biological degradation at large and enzyme-based degradation of hazardous pollutants in particular. The novel features and unique enzyme system of White Rot Fungi (WRF) are also discussed to present their potentialities and implementation against a broader spectrum of EPs/ECs. Figure 1 illustrates a schematic representation of enzyme-based degradation of hazardous contaminants.

\section{Unique enzyme system of White Rot Fungi (WRF)}

The WRF have shown great potentialities to produce two novel enzyme families with industrial and biotechnological interests i.e. (1) peroxidases that include lignin peroxidase (LiP; E.C. 1.11.1.14), manganese peroxidase (MnP; E.C. 1.11.1.13), and versatile peroxidase (VP; E.C. 1.11.1.16) among others, and (2) phenol oxidases that mainly comprised of laccases (E.C. 1.10.3.2). Both peroxidases and phenol oxidases have been or are being evaluated extensively for various applications (Iqbal et al., 2011; Asgher \& Iqbal 2011; Asgher \& Iqbal 2013; Asif et al., 2017).

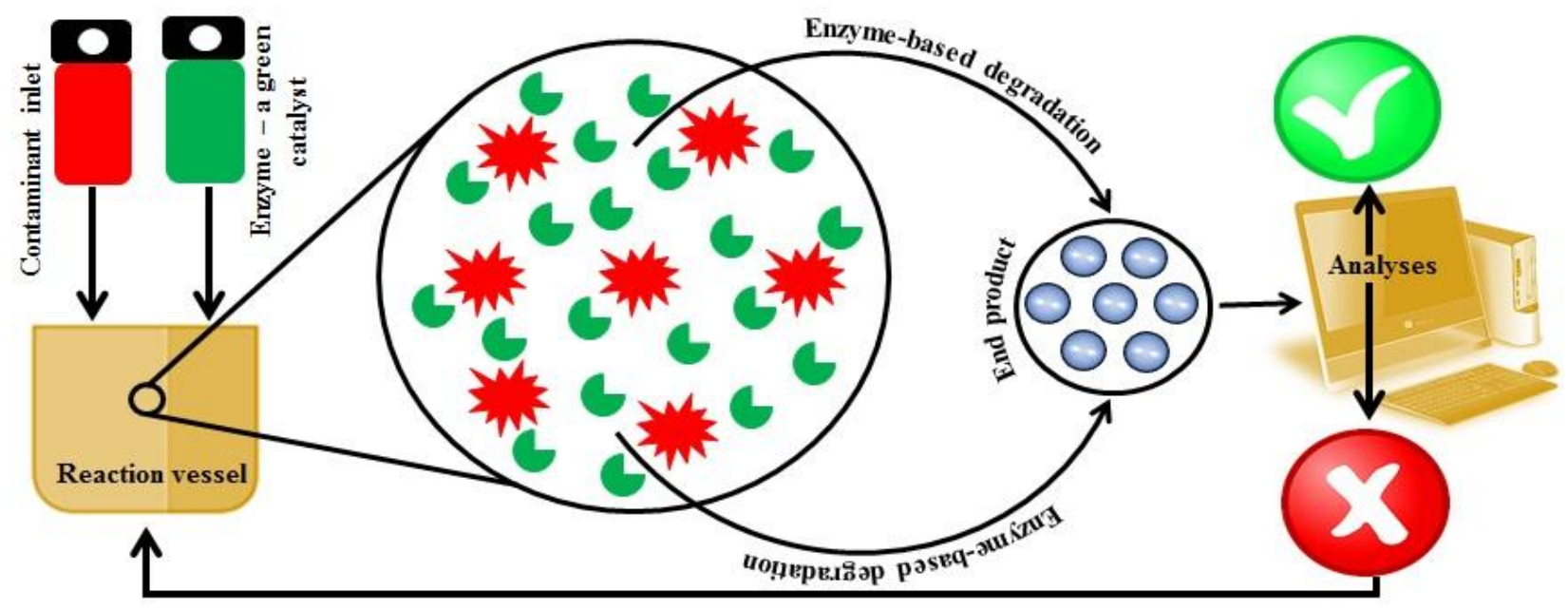

Figure 1 Enzyme-based degradation of hazardous contaminants. 
The strong oxidative capabilities, low substrate specificity, and no steric selectivity render the WRF-based peroxidases and phenol oxidases, particularly fascinating for environmental exploitability (Ashger et al., 2014).

The catalytic cycle of extracellular peroxidaes from WRF is based on two-electron oxidation process in the presence of $\mathrm{H}_{2} \mathrm{O}_{2}$. The $\mathrm{H}_{2} \mathrm{O}_{2}$, as a primary oxidant, yield compound following the oxidation of the enzyme. In the next step, electron donor substrates return the oxidized form of the enzyme into the intial state following two sequential reduction steps. The wider spectrum of extracellular peroxidaes including glyoxal oxidase, pyranose oxidase, and aryl alcohol oxidase generate $\mathrm{H}_{2} \mathrm{O}_{2}$ through direct reduction of $\mathrm{O}_{2}$ (Dosoretz \& Reddy, 2007). Laccases are the widest oxidoreductases in WRF that catalyze the fourelectron reduction of $\mathrm{O}_{2}$ to water $\left(\mathrm{H}_{2} \mathrm{O}\right)$. Likewise, $\mathrm{H}_{2} \mathrm{O}_{2}$ dependent peroxidases or $\mathrm{Mn}$-dependent peroxidaes, laccase do not require $\mathrm{H}_{2} \mathrm{O}_{2}$ or $\mathrm{Mn}(\mathrm{II})$, respectively, for its catalytic role. The unique catalytic system of laccase offer diversity in oxidizing phenolic and non-phenolic compounds via $\mathrm{O}_{2}$-dependent oxidation and free radical based oxidation, respectively (Dosoretz \& Reddy, 2007; Hofrichter et al., 2010; Rodgers et al., 2010). The oxidative mechanisms are difficult to establish because of the high reactivity of the free radicals usually involved during the breakdown processes. The unique extracellular enzyme system from WRF has shown incredible potential for removing recalcitrant pollutants from wastewater, dyes, xenobiotics, toxic aromatic hydrocarbons and endocrine disrupting chemicals EDCs (Cabana et al., 2007; Eibes et al., 2007; Bilal et al., 2017d).

\section{Biological degradation of hazardous contaminants}

An efficient degradation of the contaminants mentioned above i.e. EPs/ECs is an urgent and requisite concern and yet to be solved. Based on the literature evidence, many previous or ongoing studies have focused on contaminants degradation potentialities of various physical, chemical, and biological approaches. Among them, bio-based or biological approaches have been the focal point of recent investigations related to the dye-based contaminants and/or EPs/ECs, as the current physiochemical techniques are environmentally unattractive, and expensive (Asgher et al., 2012a; Iqbal \& Asgher, 2013; Saratale et al., 2013). Biological degradation systems that include enzyme-based degradation facilities have been widely recognized as a powerful tool for the contaminants degradation purposes (Gupta et al., 2015; Bilal et al., 2017a; Su et al., 2017). In this context, many studies have focused on direct microbial culture either fungal or bacterial and/or enzyme-based biodegradation of these contaminants effectively (Chen, 2006; Asgher et al., 2008; Asgher et al., 2009; Asgher et al., 2012a; Asgher et al., 2012b; Asgher et al., 2012c; Asgher et al., 2012d; Irshad et al., 2012; Asgher \& Iqbal 2013). Under biological treatment systems, the biodegradation involves certain enzyme-based catalysts and ultimately leads to the biotransformation of hazardous pollutants (Guieysse \& Wuertz, 2012; Norvill et al., 2016). Moreover, biobased or biological approaches (bioremediation) offers considerable advantages over physio-chemical technologies including overall cost-effective ratio, environmental friendlier process, mild reaction conditions, energy saving potentialities and wasteful protection and de-protection steps. Bioremediation is a process where removal of pollutants and xenobiotic is achieved using biological systems (including micro-organisms and their enzyme system), to degrade or at least reduce the concentration of hazardous waste (Molina-Guijarro et al., 2009; Lin et al., 2010; Asgher et al., 2012a; Asgher et al., 2012b; Asgher et al., 2012c; Asgher et al., 2012d; Waghmode et al., 2011; Yang et al., 2011; Manikandan et al., 2012; Asgher et al., 2013; Asgher et al., 2016; Bilal et al., 2016; Bilal et al., 2017a; Bilal et al., 2017b; Bilal et al., 2017c; Bilal et al., 2017d). Over the past decades, many microorganisms including bacteria, fungi, yeast, and algae have been reported for the degradation purposes (Dilek et al., 1999; Novotný et al., 2001, Asgher et al., 2008; Asgher et al., 2009; Molina-Guijarro et al., 2009; Lin et al., 2010; Ramaya et al., 2010; Asgher et al., 2012a-d; Waghmode et al., 2011; Yang et al., 2011; Manikandan et al., 2012; Asgher et al., 2013; Asgher \& Iqbal 2013; Iqbal \& Asgher 2013; Asgher et al., 2016). However, the efficacy of microbial degradation strongly depends on the adaptation and activity of the selected microorganisms. The enzyme-based catalytic engineering can be applied to the wider spectrum of various contaminants including real dyes or dye containing industrial effluents and EPs/ECs (Asgher et al., 2013). Other significant points include a complete degradation and mineralization with low environmental impact and without the use of potentially toxic chemical substances (Robinson et al., 2001).

From a critical point of view, for an efficient biodegradation of the target substances, the following point needs to be considered with utmost care i.e. (1) overall cost-effective ratio, (2) higher percent degradation ratio with respect to the processing time, (3) maintenance of optimal reaction environments, (4) controlled parameters i.e. $\mathrm{pH}$ of the reaction, incubation temperature, availability of co-reactant molecules, and target substances, (5) mild and energy saving environment, (6) recyclability of the system, (7) limited need for wasteful protection and de-protection steps, (8) competitive removal mechanisms with limited or no irreversible sorption of the target substances, and (9) no or less toxicity of the end product, if any.

Despite many useful aspects, the reaction medium to high sorption affinities of various small hydrophilic and bioavailable molecules e.g. antibiotic agents may help them in stabilization and ultimately prevents them from biodegradation (Li \& Zhang 2010; Michael et al., 2013). Even though the sorption could be a preliminary and 
Table 1 A list of enzyme-based biodegradation of hazardous contaminants or pollutants.

\begin{tabular}{|c|c|c|c|c|}
\hline Enzyme & Source & Contaminant & $\%$ removal & Reference \\
\hline Horseradish peroxidase & Horseradish roots & Remazol Brilliant Blue $\mathrm{R}$ & 82.17 & Bilal et al., 2017b \\
\hline Horseradish peroxidase & Horseradish roots & Reactive Black 5 & 97.82 & Bilal et al., 2017b \\
\hline Horseradish peroxidase & Horseradish roots & Congo Red & 94.35 & Bilal et al., 2017b \\
\hline Horseradish peroxidase & Horseradish roots & Crystal Violet & 87.43 & Bilal et al., 2017b \\
\hline $\mathrm{MnP}$ & Ganoderma lucidum IBL-05 & Nonylphenol & 96 & Bilal et al., 2017d \\
\hline $\mathrm{MnP}$ & Ganoderma lucidum IBL-05 & Triclosan & 75 & Bilal et al., 2017d \\
\hline $\mathrm{MnP}$ & Ganoderma lucidum IBL-05 & Sitara textile (SIT-based) effluent & 100 & Bilal et al., 2017d \\
\hline $\mathrm{MnP}$ & Ganoderma lucidum IBL-05 & $\begin{array}{l}\text { Crescent textile (CRT-based) } \\
\text { effluent }\end{array}$ & 95.5 & Bilal et al., 2017d \\
\hline $\mathrm{MnP}$ & Ganoderma lucidum IBL-05 & K\&N textile (KIT-based) effluent & 88 & Bilal et al., 2017d \\
\hline $\mathrm{MnP}$ & Ganoderma lucidum IBL-05 & Nishat textile (NIT-based) effluent & 84.2 & Bilal et al., 2017d \\
\hline $\mathrm{MnP}$ & Ganoderma lucidum IBL-05 & Dye-based effluents & $>94$ & Bilal et al., 2017e \\
\hline Laccase, $\mathrm{MnP}$ & Trametes versicolor IBL-04 & Remazol Brilliant Yellow-3GL & 100 & Asgher et al., 2016 \\
\hline Laccase, MnP, LiP & Schizophyllum commune IBL-06 & Solar brilliant red 80 & 100 & Asgher et al., 2013 \\
\hline Oxidoreductive enzymes & Lysinibacillus sp. RGS & C.I. Remazol Red & 100 & Saratale et al., 2013 \\
\hline Laccase & Pleurotus ostreatus IBL-02 & Drimarine blue K2RL & 100 & Asgher et al., 2012a \\
\hline Laccase & Coriolopsis polyzona & Nonylphenol & $>95$ & Cabana et al., 2007 \\
\hline Laccase & Coriolopsis polyzona & Bisphenol A & 100 & Cabana et al., 2007 \\
\hline Laccase & Coriolopsis polyzona & Triclosan & 65 & Cabana et al., 2007 \\
\hline Ligninolytic enzymes & Pleurotus ostreatus, Irpex lacteus & Remazol Brilliant Blue R & 93 & Novotný et al., 2001 \\
\hline Ligninolytic enzymes & Pleurotus ostreatus, Irpex lacteus & Bromophenol blue & 100 & Novotný et al., 2001 \\
\hline Ligninolytic enzymes & Pleurotus ostreatus, Irpex lacteus & $\mathrm{Cu}$-phthalocyanine & 98 & Novotný et al., 2001 \\
\hline Ligninolytic enzymes & Pleurotus ostreatus, Irpex lacteus & Methyl red & 56 & Novotný et al., 2001 \\
\hline Ligninolytic enzymes & Pleurotus ostreatus, Irpex lacteus & Congo red & 58 & Novotný et al., 2001 \\
\hline
\end{tabular}

important stage in the biodegradation of some pollutants (EsparzaSoto \& Westerhoff, 2003; Urase \& Kikuta, 2005; Shi et al., 2010; Norvill et al., 2016). Earlier, Nguyen et al. (2014) reported the removal of 30 different trace organic contaminants (TrOC) by comparing the role between biosorption and biodegradation. Overall, 20 to $90 \%$ degradation of four phenolic and seven nonphenolic TrOC was achieved in the presence of a redox mediator relate to the enzyme system of WRF.

\section{Enzyme-based degradation of hazardous contaminants}

The unique characteristics of WRF and their novel enzyme system with novel structural and catalytic features enables them to biodegrade a huge plethora of resistants contaminants-pollutants including original dyes or dye-based effluents, polychlorinated biphenyls, polycyclic aromatic hydrocarbons and many others as described in earlier section (Hai et al., 2008; Hai et al., 2009; Gao 
et al., 2010; Asgher et al., 2013; Chen et al., 2015; LopezEchartea et al., 2016; Asgher et al., 2016; Ahmed et al., 2017; Asif et al., 2017; Bilal et al., 2017d). Recently, Su et al. (2017) developed a novel enzyme-based biocatalyst with a remarkable thermal stability and $\mathrm{pH}$ tolerance which are considered critical parameters for industrial exploitations.

In a recent study by Asgher et al. (2016), a statistical correlation between the LMEs secretion from Trametes versicolor IBL-04 and Remazol Brilliant Yellow-3GL dye degradation has been proposed (Asgher et al., 2016). In the same study, researchers have also optimized various physicochemical and nutritional parameters including nutrient media, $\mathrm{pH}$, incubation temperature, carbon sources i.e. glucose, glycerol, starch, wheat bran, and lactose, and nitrogen sources i.e. ammonium oxalate, maize gluten meal (MGM) 30\%, MGM 60\%, and corn steep liquor (CSL) to enhance the efficiency of $T$. versicolor IBL-04 for maximum dye degradation. Furthermore, enzyme-based biodegradation of emerging endocrine disrupting contaminants e.g. nonylphenol and triclosan and dye-based pollutants has been investigated in the presence of MnP-based packed bed reactor system (Bilal et al., 2017d). Following careful optimization and characterization, an up to $80 \%$ biodegradation of both EDCs has been recorded. Whereas, the percent degradation/decolorization of dye-based effluents was varied between $84.2 \%$ to $100 \%$ in the following order, $100 \%$ for Sitara textile (SIT-based) effluent, $95.5 \%$ for Crescent Textile (CRT-based) effluent, $88.0 \%$ for K\&N textile (KIT-based) effluent and $84.2 \%$ for Nishat textile (NIT-based) effluent (Bilal et al., 2017d). Table 1 summarized a comprehensive list of enzyme-based biodegradation of hazardous contaminants/pollutants. Various authors have exploited diffent enzymes or enxyme-based immobilized constructs for degradation purposes.

\section{Considerable merits, demerits and considerations/} recommendation

\subsection{Merits}

$\checkmark \quad$ Environmental friendlier

$\checkmark \quad$ Mild and energy saving reaction environment

$\checkmark$ WRF facilitate a facile processing environment

$\checkmark \quad$ Immobilized enzymes are more effective as compared to the free counterparts

$\checkmark \quad$ Easy to adopt and inexpensive as compared to the purified or immobilized enzymes

\subsection{Demerits}

$\times \quad$ Overall mass transfer limitation

$\times \quad$ Instability against higher $\mathrm{pH}$ and temperature $\times$ Denaturation of enzymes beyond the optimal environment

$\times \quad$ Tedious work prerequisite for enzyme extraction and purification

$\times \quad$ Though efficient but overall immobilization processing is expensive

$\times \quad$ Enzymes and enzyme-related mediator washout with the treated substances

\section{Considerations/recommendation}

$>$ Catalyst washout can be avoided via immobilization engineering

$>$ Instability feature can be enhanced/improved via immobilization engineering

$>$ Denaturation of enzymes at higher $\mathrm{pH}$ and temperature conditions can be avoided via immobilization engineering

$>$ Membrane-based bioreactors coupled with engineered enzymes can be developed for efficient degradation potentialities

$>$ Using advanced molecular approaches highly active and efficient enzymes systems can be engineered as future catalysts with maximal degradation and reusability features

\section{Concluding remarks}

In conclusion, the above-reviewed data suggests that biological degradation at large and enzyme-based degradation of hazardous pollutants, in particular, are of supreme interest. Enzyme-based degradation has already been recognized as a powerful tool for the treatment or biodegradation of various types of existing or emerging contaminants. A plethora of hazardous pollutants has been efficiently treated/eliminated though using different methodologies, worldwide. However, environmental pollution is rapidly expanding with increased development in the entire industrial sector of the modern world. Owing to this heavily in practice human-made industrialization and synthetic manufacturing processes, the continuous disposal/discharge of toxic compounds with/without partial or insufficient treatments is among a major a cause of environmental contamination, both terrestrial and aquatic systems. Nonetheless, more wide-ranging and all-inclusive efforts are desirable to interpret the transformation products generated during the treatment procedures.

\section{Acknowledgement}

All the authors of the manuscript thank and acknowledge the support of their Institutes and Universities for providing literature facilities. 


\section{Disclosure statement}

Authors declare that no conflict of interest could arise.

\section{References}

Ahmed MB, Zhou JL, Ngo HH, Guo W, Thomaidis NS, Xu J (2017) Progress in the biological and chemical treatment technologies for emerging contaminant removal from wastewater: A critical review. Journal of Hazardous Materials 323: 274-298.

Arnold KE, Boxall AB, Brown AR, Cuthbert RJ, Gaw S, Hutchinson TH, Shore RF (2013) Assessing the exposure risk and impacts of pharmaceuticals in the environment on individuals and ecosystems. Biology Letter 9: 20130492.

Asgher M, Azim N, Bhatti HN (2009) Decolorization of practical textile industry effluents by white rot fungus Coriolus versicolor IBL-04. Biochemical Engineering Journal 47: 61-65.

Asgher M, Bhatti HN, Ashraf M, Legge RL (2008) Recent developments in biodegradation of industrial pollutants by white rot fungi and their enzyme system. Biodegradation 19: 771.

Asgher M, Iqbal HMN (2011) Characterization of a novel manganese peroxidase purified from solid state culture of Trametes versicolor IBL-04. Bio Resources 6: 4317-4330.

Asgher M, Iqbal HMN (2013) Enhanced catalytic features of solgel immobilized MnP isolated from solid state culture of Pleurotus ostreatus IBL-02. Chinese Chemical Letters 24: 344346.

Asgher M, Iqbal HMN, Asad MJ (2012c) Kinetic characterization of purified laccase produced from Trametes versicolor IBL-04 in solid state bio-processing of corncobs. BioResources 7: 11711188 .

Asgher M, Iqbal HMN, Irshad M (2012b) Characterization of purified and xerogel immobilized novel lignin peroxidase produced from Trametes versicolor IBL-04 using solid state medium of corncobs. BMC Biotechnology 12: 46.

Asgher M, Jamil F, Iqbal, HMN (2012d) Bioremediation potential of mixed white rot culture of Pleurotus ostreatus IBL-02 and Coriolus versicolor IBL-04 for textile industry wastewater. Journal of Bioremediation \& Biodegradation S1: 007.

Asgher M, Kamal S, Iqbal HMN (2012a) Improvement of Catalytic Efficiency, Thermo-stability and Dye Decolorization Capability of Pleurotus ostreatus IBL-02 laccase by Hydrophobic Sol Gel Entrapment. Chemistry Central Journal 6: 110.
Asgher M, Shah, SAH, Iqbal, HMN (2016) Statistical correlation between ligninolytic enzymes secretion and Remazol Brilliant Yellow-3GL dye degradation potential of Trametes versicolor IBL-04. Water Environment Research 88: 338-345.

Asgher M, Shahid M, Kamal S, Iqbal HMN (2014) Recent trends and valorization of immobilization strategies and ligninolytic enzymes by industrial biotechnology. Journal of Molecular Catalysis B: Enzymatic 101: 56-66.

Asgher M, Yasmeen Q, Iqbal, HMN (2013) Enhanced decolorization of Solar brilliant red 80 textile dye by an indigenous white rot fungus Schizophyllum commune IBL06. Saudi Journal of Biological Sciences 20: 347-352.

Asif MB, Hai FI, Singh L, Price WE, Nghiem LD (2017) Degradation of Pharmaceuticals and Personal Care Products by White-Rot Fungi-a Critical Review. Current Pollution Reports $1-16$.

Bello MM, Raman AAA, Purushothaman M (2017) Applications of fluidized bed reactors in wastewater treatment-A review of the major design and operational parameters. Journal of Cleaner Production 141: 1492-1514.

Bilal M, Asgher M, Iqbal HMN, Hu H, Wang W, Zhang X (2017e) Bio-catalytic performance and dye-based industrial pollutants degradation potential of agarose-immobilized MnP using a Packed Bed Reactor System. International Journal of Biological Macromolecules 102: 582-590.

Bilal M, Asgher M, Iqbal HMN, Hu H, Zhang X (2017d) Biobased degradation of emerging endocrine-disrupting and dyebased pollutants using cross-linked enzyme aggregates. Environmental Science and Pollution Research 24: 7035-7041.

Bilal M, Asgher M, Parra-Saldivar R, Hu H, Wang W, Zhang X, Iqbal HMN (2017a) Immobilized ligninolytic enzymes: An innovative and environmental responsive technology to tackle dye-based industrial pollutants-A review. Science of The Total Environment 576: 646-659.

Bilal M, Iqbal HMN, Hu H, Wang W, Zhang X (2017b) Enhanced bio-catalytic performance and dye degradation potential of chitosan-encapsulated horseradish peroxidase in a packed bed reactor system. Science of The Total Environment 575: 13521360 .

Bilal M, Iqbal HMN, Hu H, Wang W, Zhang X (2017c) Development of horseradish peroxidase-based cross-linked enzyme aggregates and their environmental exploitation for 
bioremediation purposes. Journal of Environmental Management 188: 137-143.

Bilal M, Iqbal HMN, Shah SZH, Hu H, Wang W, Zhang X (2016) Horseradish peroxidase-assisted approach to decolorize and detoxify dye pollutants in a packed bed bioreactor. Journal of Environmental Management 183: 836-842.

Bolong N, Ismail AF, Salim MR, Matsuura T (2009) A review of the effects of emerging contaminants in wastewater and options for their removal. Desalination 239: 229-246.

Brookes JD, Carey CC, Hamilton DP, Ho L, van der Linden L, Renner R, Rigosi A (2014) Emerging challenges for the drinking water industry. Environmental Science and Technology 48: 20992101.

Cabana H, Jiwan JLH, Rozenberg R, Elisashvili V, Penninckx M, Agathos SN, Jones JP (2007) Elimination of endocrine disrupting chemicals nonylphenol and bisphenol A and personal care product ingredient triclosan using enzyme preparation from the white rot fungus Coriolopsis polyzona. Chemosphere 67: 770-778.

Chatha SAS, Asgher M, Iqbal HMN (2017) Enzyme-based solutions for textile processing and dye contaminant biodegradation - a review. Environmental Science and Pollution Research 24: 14005-14018.

Chen H (2006) Recent advances in azo dye degrading enzyme research. Current Protein and Peptide Science 7: 101-111.

Chen M, Xu P, Zeng G, Yang C, Huang D, Zhang J (2015) Bioremediation of soils contaminated with polycyclic aromatic hydrocarbons, petroleum, pesticides, chlorophenols and heavy metals by composting: applications, microbes and future research needs. Biotechnology Advances 33: 745-755.

Deblonde T, Cossu-Leguille C, Hartemann P (2011) Emerging pollutants in wastewater: a review of the literature. International Journal of Hygiene and Environmental Health 214: 442-448.

Dilek FB, Taplamacioglu HM, Tarlan E (1999) Colour and AOX removal from pulping effluents by algae. Applied Microbiology and Biotechnology 52: 585-591.

Ding C, He J (2010) Effect of antibiotics in the environment on microbial populations. Applied Microbiology and Biotechnology 87: 925-941.

Dosoretz CG, Reddy CA (2007) Lignin and lignin-modifying enzymes. Methods for general and molecular microbiology, 3rd edn. American Society for Microbiology, Washington Pp. 611620.
Eibes G, López C, Moreira MT, Feijoo G, Lema JM (2007) Strategies for the design and operation of enzymatic reactors for the degradation of highly and poorly soluble recalcitrant compounds. Biocatalysis and Biotransformation 25: 260-268.

Esparza-Soto M, Westerhoff P (2003) Biosorption of humic and fulvic acids to live activated sludge biomass. Water Research 37 : 2301-2310.

\section{EUROSTAT.}

http://epp.eurostat.ec.europa.eu/tgm/table.do?tab=table\&init=1\& plugin $=1 \&$ language $=$ en $\&$ p code $=$ ten 00011 .

Filali-Meknassi Y, Tyagi RD, Surampalli RY, Barata C, Riva MC (2004) Endocrine-disrupting compounds in wastewater, sludgetreatment processes, and receiving waters: Overview. Practice Periodical of Hazardous, Toxic, and Radioactive Waste Management 8: 39-56.

Gao D, Du L, Yang J, Wu WM, Liang H (2010) A critical review of the application of white rot fungus to environmental pollution control. Critical Reviews in Biotechnology 30: 70-77.

Gavrilescu M, Demnerová K, Aamand J, Agathos S, Fava F (2015) Emerging pollutants in the environment: present and future challenges in biomonitoring, ecological risks and bioremediation. New Biotechnology 32: 147-156.

Guieysse B, Wuertz S (2012) Metabolically versatile largegenome prokaryotes. Current Opinion in Biotechnology 23: 467473.

Gupta S, Pathak B, Fulekar MH (2015) Molecular approaches for biodegradation of polycyclic aromatic hydrocarbon compounds: a review. Reviews in Environmental Science and Bio/Technology 14: 241-269.

Hai FI, Yamamoto K, Nakajima F, Fukushi K (2008) Removal of structurally different dyes in submerged membrane fungi reactor-Biosorption/PAC-adsorption, membrane retention and biodegradation. Journal of Membrane Science 325: 395-403.

Hai FI, Yamamoto K, Nakajima F, Fukushi K (2009) Factors governing performance of continuous fungal reactor during nonsterile operation-the case of a membrane bioreactor treating textile wastewater. Chemosphere 74: 810-817.

Hofrichter M, Ullrich R, Pecyna MJ, Liers C, Lundell T (2010) New and classic families of secreted fungal heme peroxidases. Applied Microbiology and Biotechnology 87: 871897.

Iqbal HMN, Asgher M (2013) Characterization and decolorization applicability of xerogel matrix immobilized manganese 
peroxidase produced from Trametes versicolor IBL-04. Protein and Peptide Letters 20: 591-600.

Iqbal HMN, Asgher M, Bhatti HN (2011) Optimization of physical and nutritional factors for synthesis of lignin degrading enzymes by a novel strain of Trametes versicolor. BioResources 6: 1273-1287.

Irshad M, Bahadur BA, Anwar Z, Yaqoob M, Ijaz A, Iqbal HMN (2012) Decolorization applicability of sol-gel matrix-immobilized laccase produced from Ganoderma leucidum using agro-industrial waste. BioResources 7: 4249-4261.

Lapworth DJ, Baran N, Stuart ME, Ward RS (2012) Emerging organic contaminants in groundwater: a review of sources, fate and occurrence. Environmental Pollution 163: 287-303.

Li B, Zhang $\mathrm{T}$ (2010) Biodegradation and adsorption of antibiotics in the activated sludge process. Environmental Science \& Technology 44: 3468-3473.

Lin J, Zhang X, Li Z, Lei L (2010) Biodegradation of Reactive blue 13 in a two-stage anaerobic/aerobic fluidized beds system with a Pseudomonas sp. isolate. Bioresource Technology 101: 3440 .

Liu ZH, Kanjo Y, Mizutani S (2009) Removal mechanisms for endocrine disrupting compounds (EDCs) in wastewater treatment-physical means, biodegradation, and chemical advanced oxidation: a review. Science of the Total Environment 407: 731-748.

Lopez-Echartea E, Macek T, Demnerova K, Uhlik O (2016) Bacterial Biotransformation of Pentachlorophenol and Micropollutants Formed during Its Production Process. International Journal of Environmental Research and Public Health 13: 1146.

Manikandan N, Kuzhali RS, Kmuthakalavalli R (2012) Decolourization of textile dye effluent using fungal microflora isolated from spent mushroom substrate (SMS). J Microbiol Biotech Res 2: 57-62.

Marcoux MA, Matias M, Olivier F, Keck G (2013) Review and prospect of emerging contaminants in waste-Key issues and challenges linked to their presence in waste treatment schemes: General aspects and focus on nanoparticles. Waste Management 33: 2147-2156.

Michael I, Rizzo L, McArdell CS, Manaia CM, Merlin C, Schwartz T, Fatta-Kassinos D (2013) Urban wastewater treatment plants as hotspots for the release of antibiotics in the environment: a review. Water Research 47: 957-995.
Molina-Guijarro JM, Pérez Torres J, Muñoz-Dorado J, Guillén Carretero F, Moya Lobo R, Hernández Cutuli M, Arias Fernández ME (2009) Detoxification of azo dyes by a novel $\mathrm{pH}$-versatile, salt-resistant laccase from Streptomyces ipomoea. International Microbiology 12: 13-21.

Nguyen LN, Hai FI, Yang S, Kang J, Leusch FD, Roddick F, Nghiem LD (2014) Removal of pharmaceuticals, steroid hormones, phytoestrogens, UV-filters, industrial chemicals and pesticides by Trametes versicolor: role of biosorption and biodegradation. International Biodeterioration \& Biodegradation 88: 169-175.

Norvill ZN, Shilton A, Guieysse B (2016) Emerging contaminant degradation and removal in algal wastewater treatment ponds: Identifying the research gaps. Journal of Hazardous Materials 313: 291-309.

Novotný Č, Rawal B, Bhatt M, Patel M, Šašek V, Molitoris HP (2001) Capacity of Irpex lacteus and Pleurotus ostreatus for decolorization of chemically different dyes. Journal of Biotechnology 89: 113-122.

Ramya M, Iyappan S, Manju A, Jiffe JS (2010) Biodegradation and decolorization of acid red by Acinetobacter radioresistens. Journal of Bioremediation \& Biodegradation 1 : $10-4172$.

Robinson T, McMullan G, Marchant R, Nigam P (2001) Remediation of dyes in textile effluent: a critical review on current treatment technologies with a proposed alternative. Bioresource Technology 77: 247-255.

Rodgers CJ, Blanford CF, Giddens SR, Skamnioti P, Armstrong FA, Gurr SJ (2010) Designer laccases: a vogue for high-potential fungal enzymes?. Trends in Biotechnology 28: 63-72.

Romero S, Blánquez P, Caminal G, Font X, Sarrà M, Gabarrell X, Vicent T (2006) Different approaches to improving the textile dye degradation capacity of Trametes versicolor. Biochemical Engineering Journal 31: 42-47.

Saratale RG, Gandhi SS, Purankar MV, Kurade MB, Govindwar SP, Oh SE, Saratale GD (2013) Decolorization and detoxification of sulfonated azo dye CI Remazol Red and textile effluent by isolated Lysinibacillus sp. RGS. Journal of Bioscience and Bioengineering 115: 658-667.

Shi W, Wang L, Rousseau DP, Lens PN (2010) Removal of estrone, 17 $\alpha$-ethinylestradiol, and 17ß-estradiol in algae and duckweed-based wastewater treatment systems. Environmental Science and Pollution Research 17: 824-833. 
Snyder S, Vanderford B, Pearson R, Quinones O, Yoon Y (2003) Analytical methods used to measure endocrine disrupting compounds in water. Practice Periodical of Hazardous, Toxic, and Radioactive Waste Management 7: 224-234.

Su FH, Tabañag IDF, Wu CY, Tsai SL (2017) Decorating outer membrane vesicles with organophosphorus hydrolase and cellulose binding domain for organophosphate pesticide degradation. Chemical Engineering Journal 308: 1-7.

Thomaidis NS, Asimakopoulos AG, Bletsou AA (2012) Emerging contaminants: a tutorial mini-review. Global NEST Journal 14: $72-79$.

Urase T, Kikuta T (2005) Separate estimation of adsorption and degradation of pharmaceutical substances and estrogens in the activated sludge process. Water Research 39: 1289-1300.

Verlicchi P, Al Aukidy M, Zambello E (2012) Occurrence of pharmaceutical compounds in urban wastewater: removal, mass load and environmental risk after a secondary treatment-a review. Science of the Total Environment 429: 123-155.

Waghmode TR, Kurade MB, Govindwar SP (2011) Time dependent degradation of mixture of structurally different azo and non azo dyes by using Galactomyces geotrichum MTCC 1360. International Biodeterioration \& Biodegradation 65: 479486.

WWF

TOXIC

CHEMICALS.

http://wwf.panda.org/about_our_earth/teacher_ resources/webfieldtrips/toxics/.

Yang Y, Hu H, Wang G, Li Z, Wang B, Jia X, Zhao Y (2011) Removal of malachite green from aqueous solution by immobilized Pseudomonas sp. DY1 with Aspergillus oryzae. International Biodeterioration \& Biodegradation 65: 429-434. 